\title{
الاستثناء من حكم الالحاق بالتملك \\ في القانون الفرنسي
}

\section{The exception from the rule of annexation of ownership in French law}

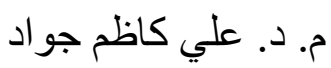

قسم تقنيات الادارة القانونية

معهد الادارة التقني

الجامعة التقنية الوسطى

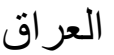

Dr.Ali Kadhim Jawad

Department of Legal

Administration

Technical Institute for

Administration

Middle Technical University

Iraq
}

Email: Dr.Ali.Kadhim@mtu.edu.iq

$$
\begin{aligned}
& \text { أ م. د. مثنى محمد عبد } \\
& \text { قسم تقنيات الادارة القانونية } \\
& \text { معهذ الادارة التقني } \\
& \text { الجامعة التقنية الوسطى } \\
& \text { العر اق }
\end{aligned}
$$

Dr. Muthana Mohammed Abid

Department of Legal Administration

Technical Institute for Administration

Middle Technical University

Iraq

Email: Dr.Muthana.M.Abd@mtu.edu.iq 


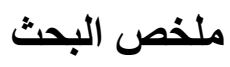

قد يجتمع الماللك و الحائز في شخصا واحد ، وفي هذه الحالة فأن من يملك الثيء يملك ثماره . ولكن قد يختلف شخص الماللك عن الحائز ـ وهو ما يحدث اذا نجح المالك الاصلي في استرداد

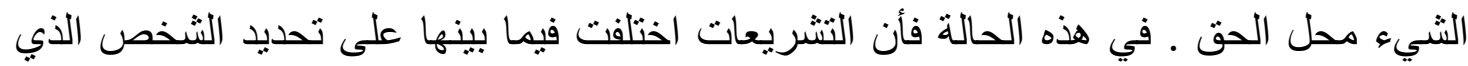

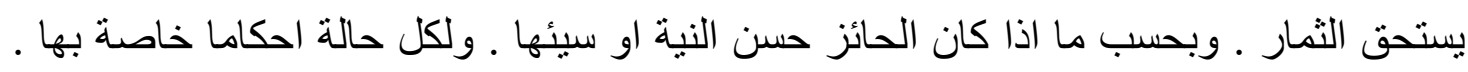

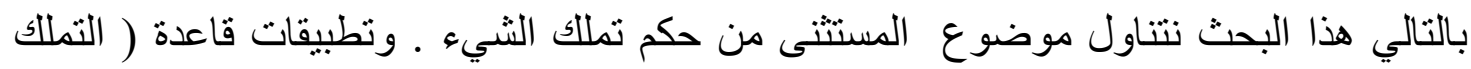
بالحيازة ) والتي تنتمي الى القواعد الحديثة في القانون الروماني وكذلك وجهة نظر القانون المدني العر اقي. الكلمات المفتاحية : الثمار ، الحائز, تملك ، حسن النية ، سيء النية.

\begin{abstract}
The owner and possessor may meet in one person, thus who have these property they have its fruit. But in sometimes the owner is different than possessor, this happen in case the original owner succeeds in recovering his property or right. About that the legislations differed on the determination the person who deserves the fruits and whether the possessor is bona fide or mala fide. This paper is focused on the idea of the excluded from the rule of possession of the thing. And the applications of the rule (acquisition by possession) that belong to modern Roman law also the standpoint of Iraqi law.
\end{abstract}

Keywords: Fruits, Possessor, owner, Bona fide, Mala fide. 


\section{المقدمة}

\section{Introduction}

أذا تو افرت شروط التقادم الطويل او القصير ، فان ذلك يؤدي الى كسب ملكية المنقول أو

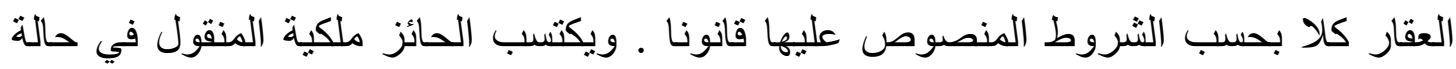

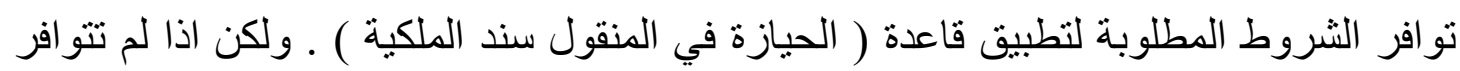
شروط التقادم بنوعيه السابقين ، أو فقدت قاعدة الحيازة أحد اركانها ــ و اثبت الماللك حق ملكيته

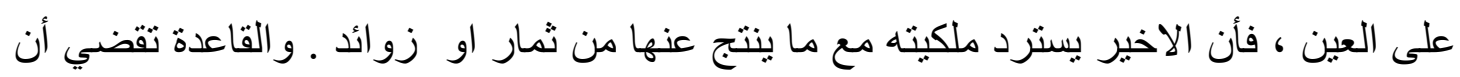

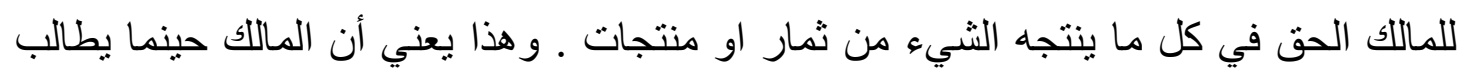

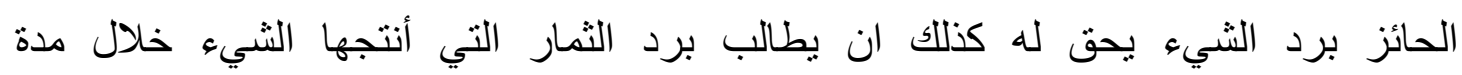

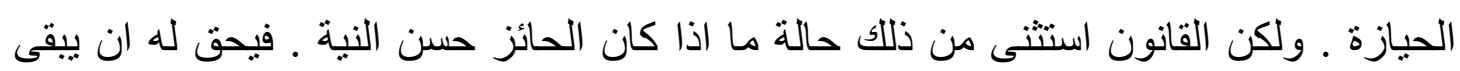

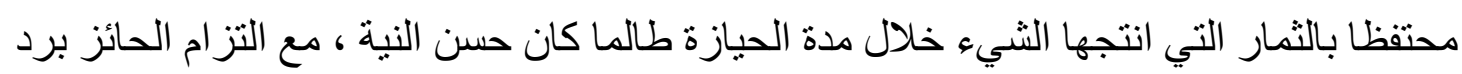

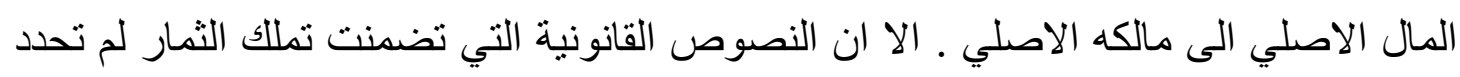

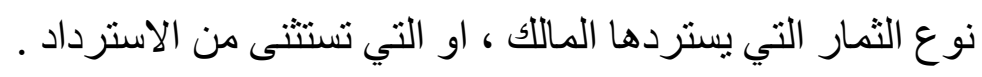

أثنكالية البحث : اذا كان الحائز قد حصل على الثيء بموجب عقد باطل او معلق على شرط

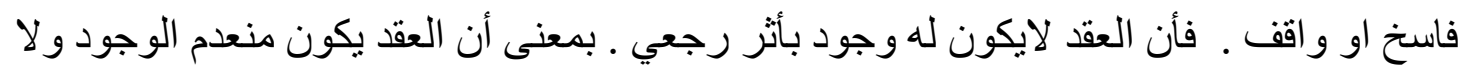

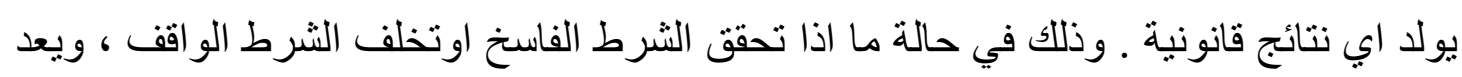
العقد كأن لم يكن ، ومن ثم يسترد المالك العين المملوكة من الحائز ـ فمصير الثمار هنا يبقى ولثي

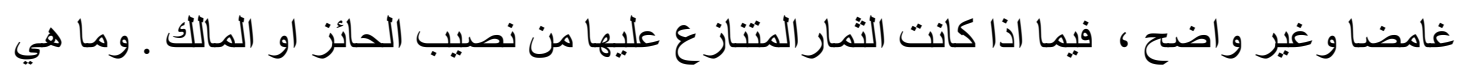
الاثار المترتبة على تملك اي منهما للثمار.

منهجية البحث : في ضوء الاشكالية السابقة ، نقسم موضوع البحث على مبحثين ، الاول يتناول احكام تملك ثمار الثيء بالحيازة ـ و الثاني في الاساس القانوني لتملك الثمار ، ثم نختم البحث

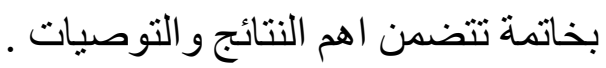




\section{المبحث الاول}

\section{قاعدة تملك الثمار بالحيازة}

\section{The rule of acquisition the fruits by possession}

الاصل في القانون المدني الفرنسي و العراقي ، أن المالك له الحق على ثمار الثيء ، فيكتسب ملكية الثمار و الزوائد ، حسبما نصت عليه المادة (

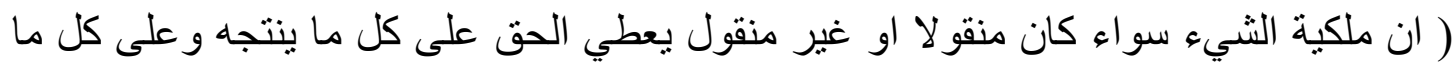

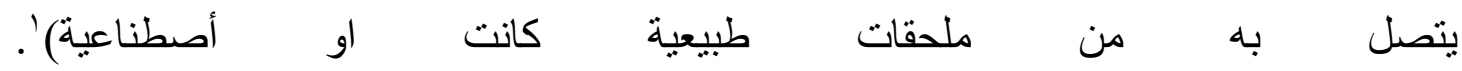

و هو ما نصت عليه المادة ( ^^ـ ـ 1 ) من القانون المدني العر اقي ( الملك التام من شأنه ان

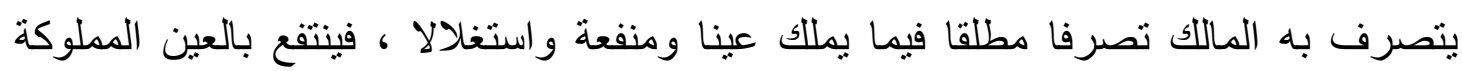

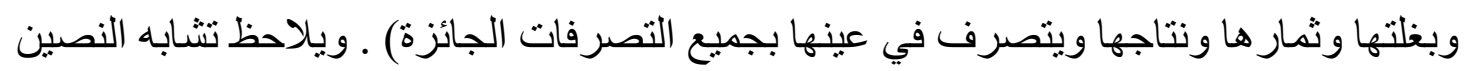

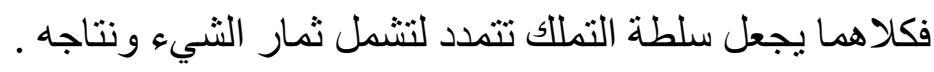

الا ان هذه الاصل يرد عليه استثناء يتعلق بتملك الحائز للثمار ، في حالة اذا كان حسن النية وهذا الاستثناء نص القانون المدني الفرنسي في المادة ( •00 ) منه (يكون الحائز حسن النية

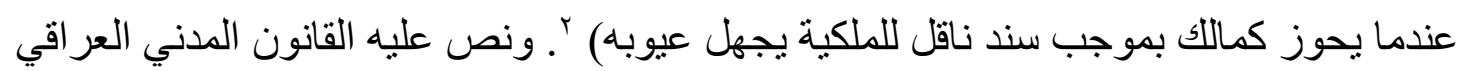
في المادة ( 170 (1) ) من القانون المدني العر اقي التي تعطي الحق للحائز حسن النية بتملك الثمار

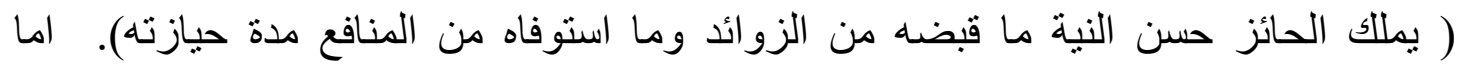
المنتجات فتكون من حق المالك ـ و هنا ينبغي التمييز بين الثمار و المنتجات ـ فالثمار هي ما ينتجه

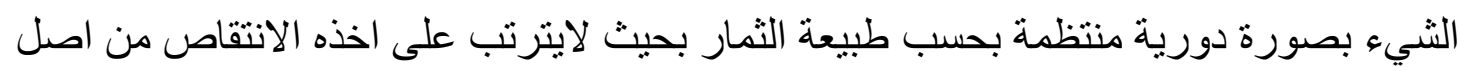

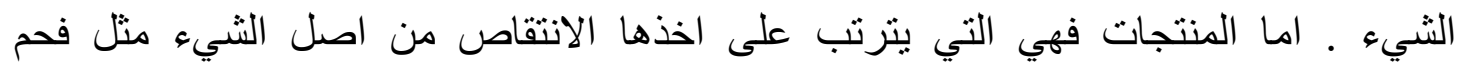

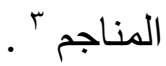




\section{المطلب الاول \\ مفهوم الثمار وانواعها}

\section{The concept and types of fruits}

الثمار هي ما ينتج من الثيء نتاجا بحسب طبيعته دون اي نقص او تغيير ظاهر يصيب

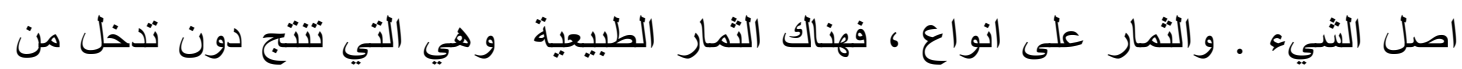

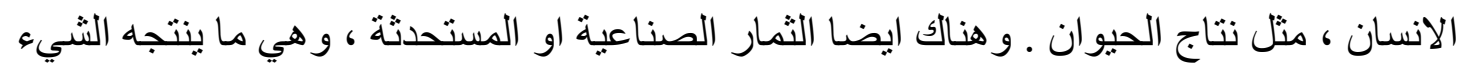

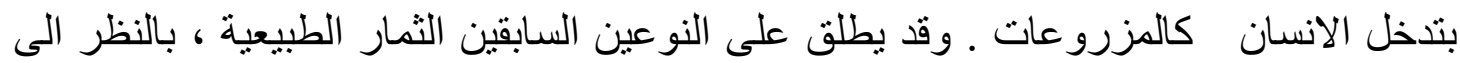

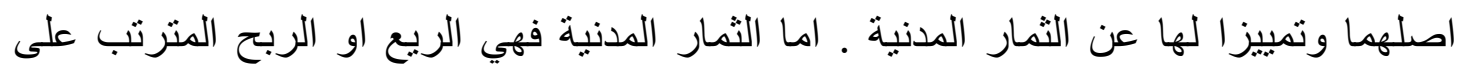

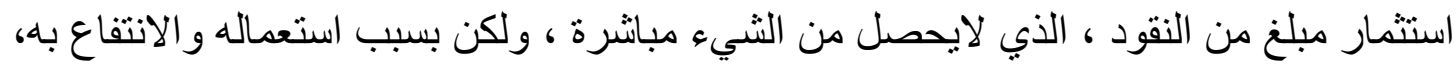

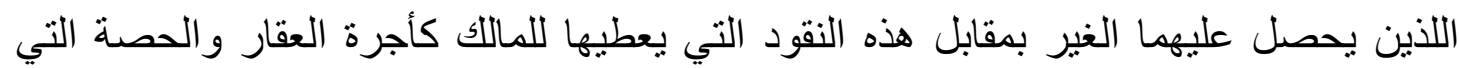

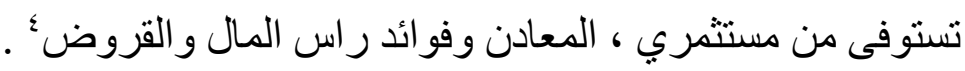

وطبقا لنص المادة ( V V ) من القانون المدني الفرنسي (أن ثمار الارض الطبيعية أو

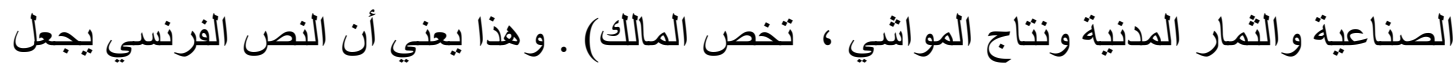
تملك الثمار على اختلاف انواعها من نصيب المالك ـ ولكن بشروط محددة نصت عليها المادة

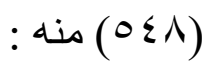

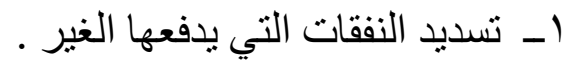
r أن أنقدر قيمة النفقات وقت التسديد .

هذا وان القضاء الفرنسي يعطي لقاضي الموضوع صلاحية تقدير قيمة النفقات بنسبة مئوية من

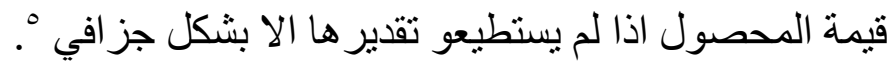

ولكن الحائز في القانون الددني العر اقي يملك هذه الانواع الثلاثة من الثمار اذا كانت قد

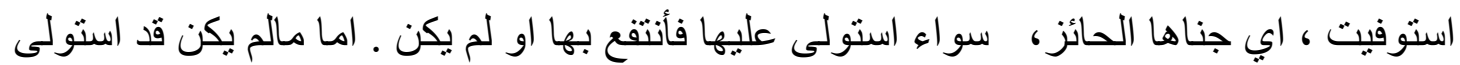

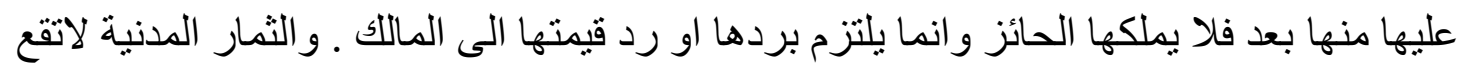
ملكية الحائز عليها كما تقع في الثمار الطبيعية و الصناعية ، اذ ان هذه تحتاج في الاستيلاء عليها

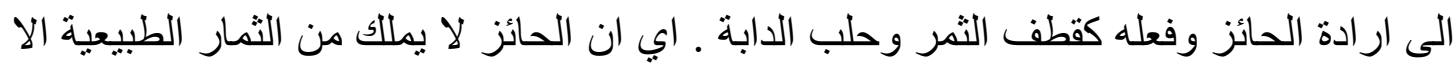


ما كان قد فصله من الثيء بار ادته واستولى عليه ـ و المعنى المخالف لهذا ، ان الحائز لايملك الثمار مالم يفصلها بار ادته وقصده ، كالثمار و الخضروات التي تنفصل من تلقاء نفسها ، او بحادث طبيعي أو بفعل الغير ـ كما لا يملك ما ابقاه منها في اصلها حتى وقت رد الثيء الى لى مالكه ـ اما الثمار المدنية فأن الاستيلاء عليها لايقع الا بفعل القبض " ـ لهذا فأن الحائز لايملك منها الاما دفع له فقبضه ـ اي ان الاستيلاء عليها يقع بالقبض من الغير فمتى قبضها ملكها وسواء بعد هذا ان يقبضها قبل الاستحقاق ام بعده ـ مثال ذلك العقار الذي يؤجره الحائز حسن النية فيقضض اجرته مقدما ، ثم برفع الدعوى مالك العقار فيسترده قبل انتهاء الددة التي لغي قبض عنها الاجرة ـ و الفائدة التي يقبضها عن القرض مقدما فأنه لايملكها ولا يلزم برد شيء غير

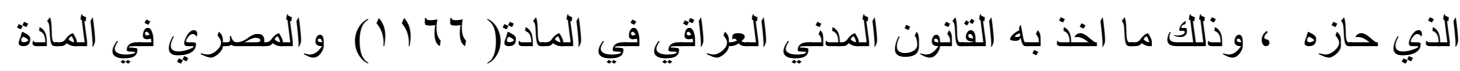
. (

اما ما عدا الثمار الطبيعية والمدنية فلا يملكه الحائز ، لأن النص قاصر على هذه

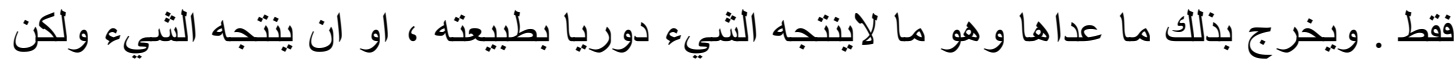

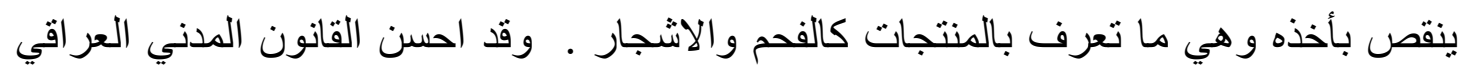

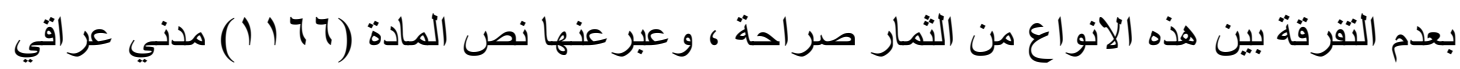
بـ ( الزوائد والمنافع ) ـ وجعل تملك الحائز حسن النية للزوائد ، ( وتثمل الثمار الطبيعية

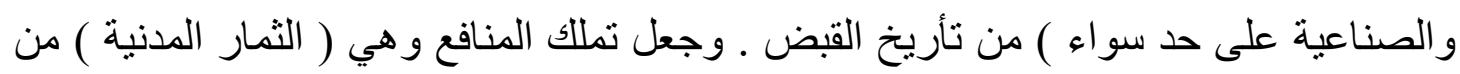

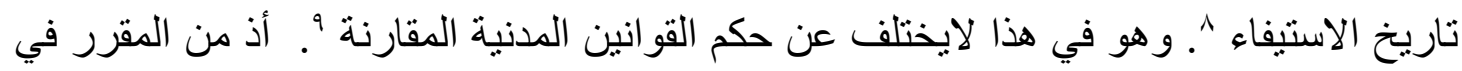

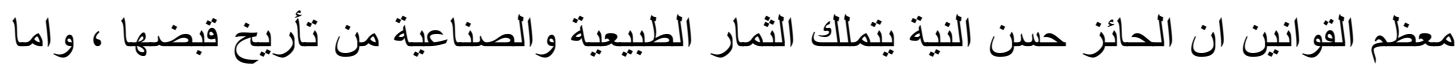
الثمار المدنية فأنها تعد مقبوضة يوما فيوم ، حسب تعبير نص المادة ( 9У^ ) مدني

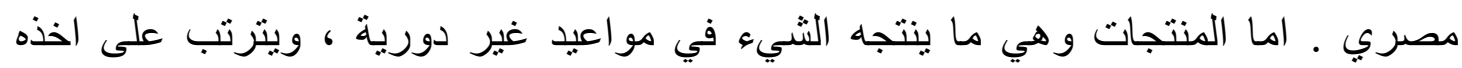

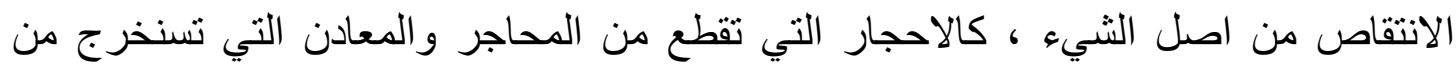

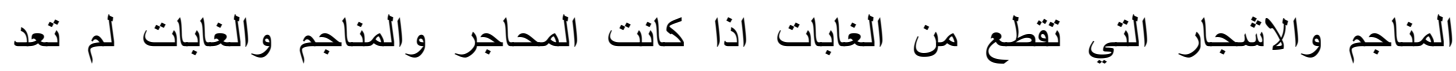
للاستغلال '. وبناءا على ذلك فأن المنتجات تتميز بما يأتي : ا ـ غير دورية ولا متجددة ، بل تخرج من الثيء في اوقات متقطعة غيرمنتظمة . r_ تمس اصل الثنيء وتنتقص منه ، فالمعادن التي تخرج من المناجم و الاحجار التي تخرج من

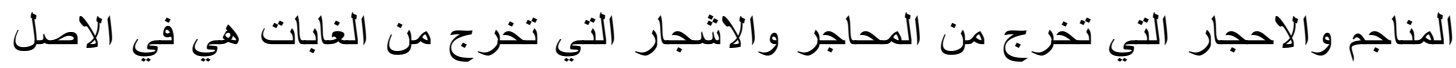


منتجات لا ثمار ، لأنها تنقص من المناجم والمحاجر و الغابات وتتنهي الى ان تتفذ بعد وقت

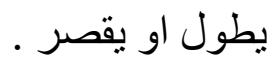

على انه اذا اعد المنجم او المحجر او الغابة للاستغلال بحيث يمكن الحصول منها على ايراد

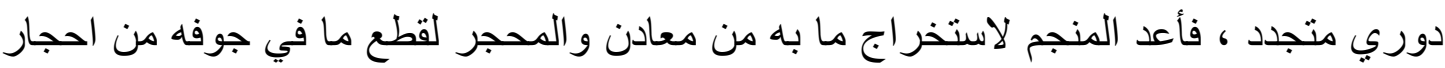

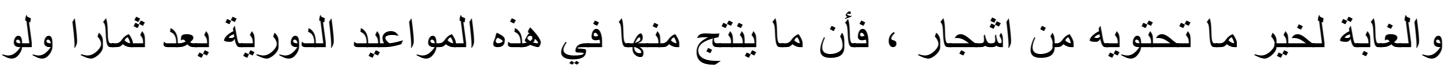

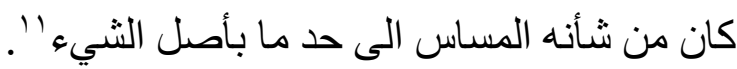

$$
\text { المطلب الثاني }
$$

شروط تملك الثمار

\section{Conditions of possession the fruits}

بحسب نصوص القانون المدني الفرنسي والعراقي ، فأنه يشترط لكسب ملكية الحائز للثمار

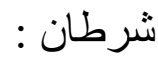

الاول : جني الحائز للثمار : يشترط لتطبيق قاعدة تملك الثمار بالحيازة ، ان يقبض الحائز الثمار

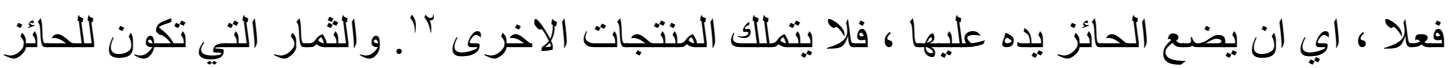

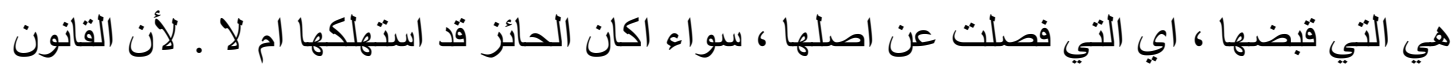
لا يفرق بين الحالتين ، اما الثمار التي لاتزال متصلة فلا يستحقها الحائز ـ ويشترط ان يكون

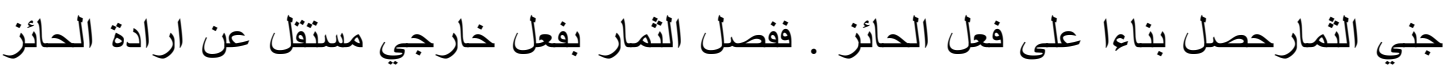
لايكفي ـ بل يجب ان يوجد فعل صادر عن ار ادته .

و هذا الحكم وان لم يذكر صر احة في القانون الفرنسي النافذ الا انه كان منصوصا عليه في

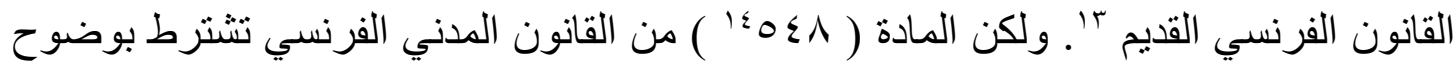
لاكتساب المالك ملكية الثمار ان يسدد المالك النفقات التي تكبدها الغير لانتاج الثمار ـ و التي تقدر

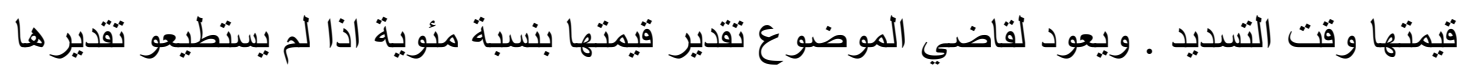

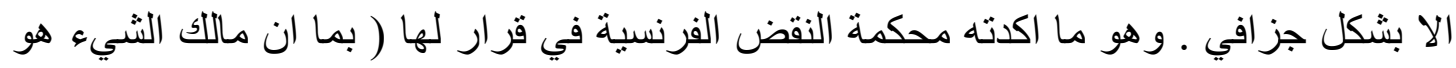




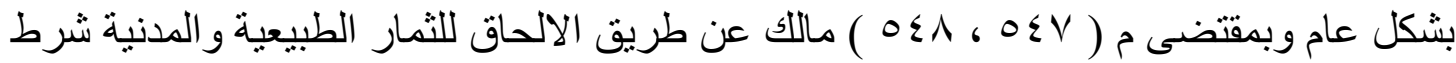

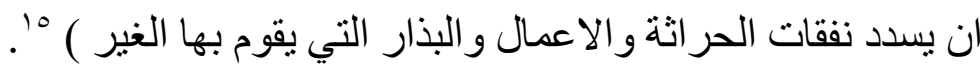

ونؤيد من يذهب الى ضرورة الاخذ به في القانون المدني العراقي ـ وهذا يعني ان القانون فرق بين الثمار الطبيعية والثمار المستحدثة من ناحية ، وبين الثمار المدنية من ناحية اخرى ـ اما

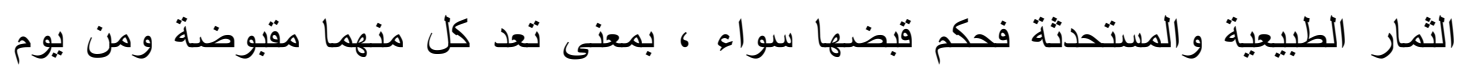
فصلها" . فيلزم لكسب الحائز للثمار ان يكون قد قبضها ، اما تللك التي لم يقبضها فلا سلطان له له عليها ـ ذلك ان الثمار التي قبضها غالبا ما يكون قد استهلكها فيكون الزامه بردها افقارله ـ اما لها

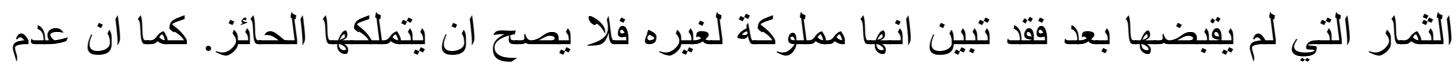

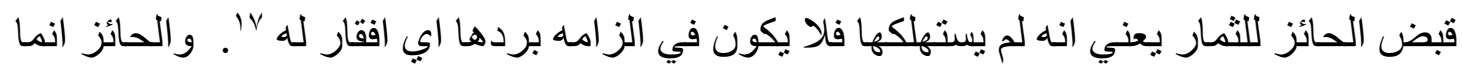

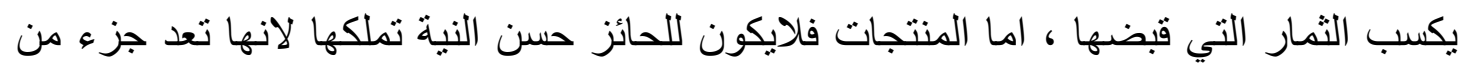

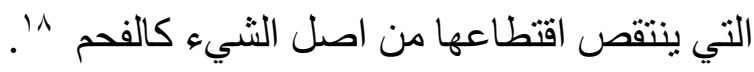

الثاني : حسن النية : وضع القانون المدني الفرنسي اصلا عاما فيما يعد حسن النية ـ أذ نصت

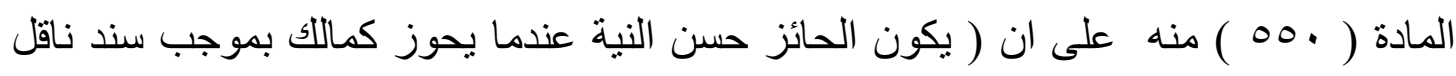

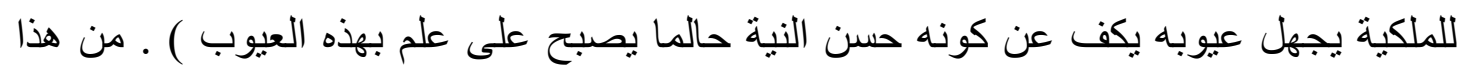

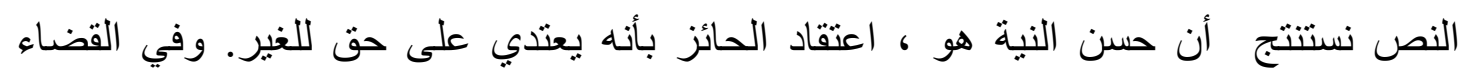

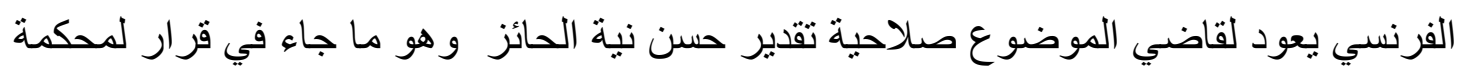
النقض ـ ( يقدر قضاة الموضو ع بسلطان مطلق حسن نية الحائز ) 19 .

وتتص المادة ( 9 ؟0) من القانون المدني الفرنسي على أنه (لا يمنللك الحائز العرضي البسيط الثمار الا في الحالة التي يكون فيها حسن النية ) ـ وهو ما قضت بن بهن محكمة النقض الفرنسية

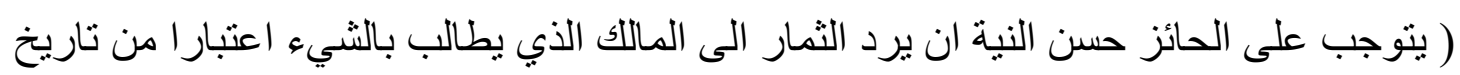

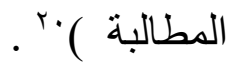

ولكن حسن النية في تملك الثمار يندمج مع السبب الصحيح ـ ومن ثم فأن حسن النية في

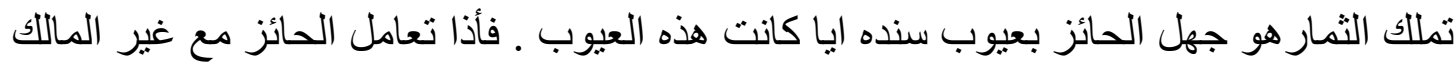
، فان جهل ذللك واعتق الحائز ان من تلقى منه العين هو المالك ، فهو حسن النية اذا لم يكن السند

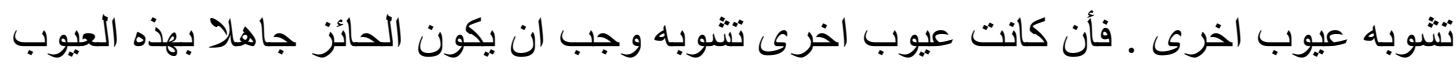
حتى يكون حسن النية. واذا كان قد تعامل مع الماللك وكان سنده مشوبا بعيب كأن يكون باطلا. r. 
وجب ان يكون جاهلا بالعيب حتى يكون حسن النية' ـ فحسن النية في تملك الثمار معناه اذن ان يعتقد الحائز انه تملك العين التي انتجت هذه الثمار ملكا صحيحا لا تشوبه شائبة وان ملكية العين

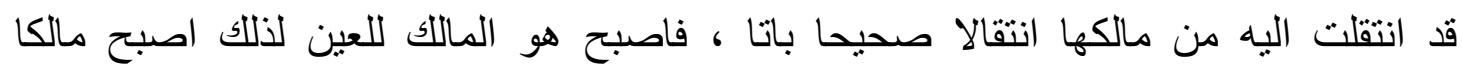

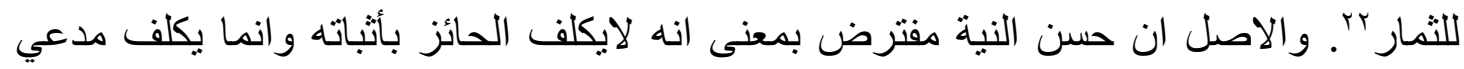
العكس بأثبات ما يدعيه من سوء نبة الحائز ـ ويمكن التوصل الى هذا الاثبات من خلال اثبات

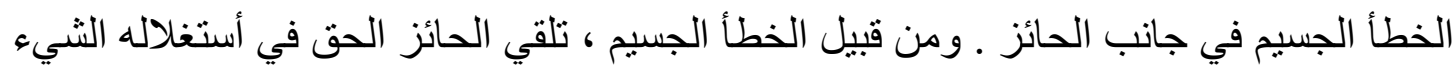
بمقتضى سند باطل بطلانا مطلقا مؤسسا على مخالفة النظام العام ـ فلا يكون جهله اذن بهذا

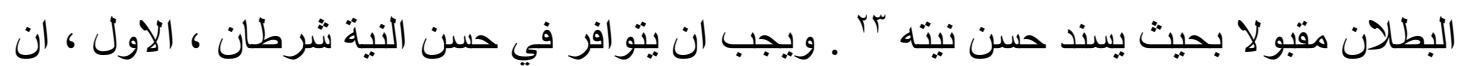

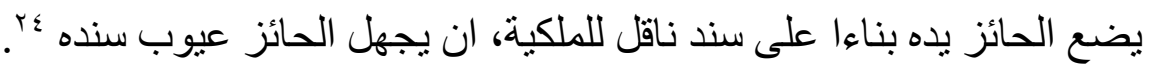

اولا: ان يضع الحائزيده على ثمار الثيء بناءا على سند ناقل للملكية ، نعني بالسند الناقل

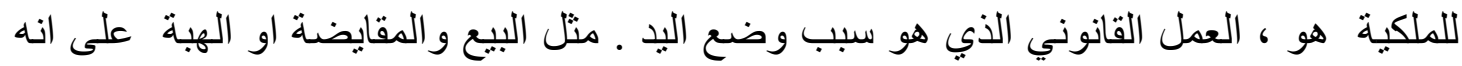

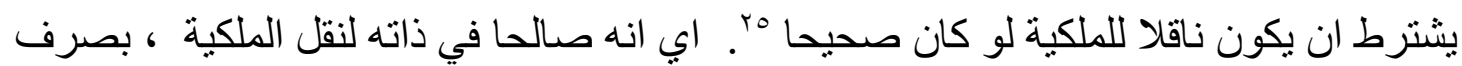
النظر عن صدوره من المالك الحقبقي او من سواه ، وعن كون الثخص الذي صدر منه العقد

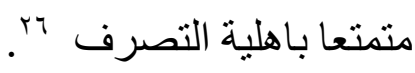
ثانيا : ان يجهل الحائز عيوب السند ، وينبغي ان يكون الحائز جاهلا عيوب السند ، او جاهلا للاسباب التي تمنع العمل القانوني من احداث اثره الذي يترتب عليه نقل الملكية ـ لافرق بين العيوب المتعلقة بالثكل او بالموضوع ـ و لا بين العيوب التي يترتب عليها بطلان العمل

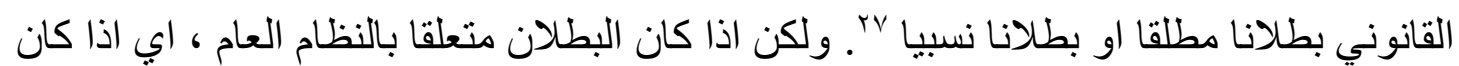
العيب فيه مخالفة لنص متعلق بالنظام العام ، فأنه لايكون للسند اية قيمة ولو كان الحائز يجهل ذللك العيب ^^هذا ويلاحظ ان حسن النية الذي ينطلبه القانون يجب ان يكون مطلقا اي متعلقا بالعيوب التي تثنوب السند مهما كانت وَ. و وذا ما قضت به محكمة النقض الفرنسية في قرار

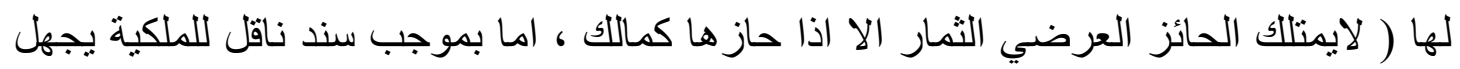

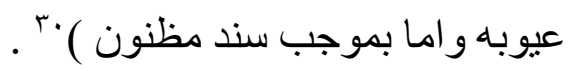

ويذهب بعض الفقهاء الى ان السند الظني يجيز تملك الثمار منى كان الحائز يعتقد وجود

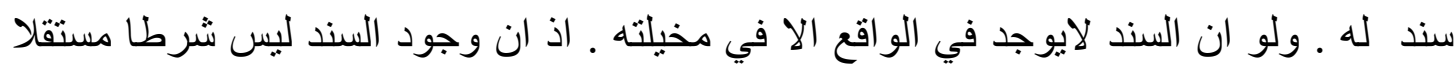

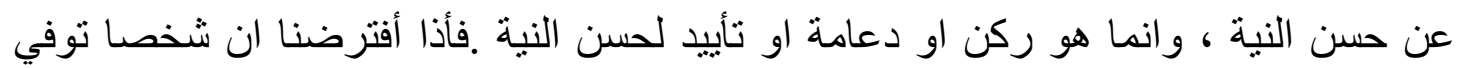


وترك امو الا، فوضع قريب له يده عليها بأعتقاده انه وارثه ، ولكن وجد بعد وارث اقرب منه تؤول اليه الاموال المتروكة . فسند الاول وهمي ، كونه لم يوجد الافي مخيلة الحائز ، ولكنه كان

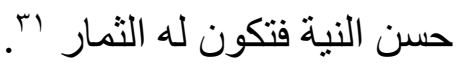

\section{المطلب الثالث}

احكام قاعدة تملك الثمار بالحيازة

\section{The provisions of rule for acquisition the fruits by possession}

يترتب على تطبيق قاعدة ( تملك الثمار بالحيازة ) ، احكام نصت على بعضها المو اد ( 110

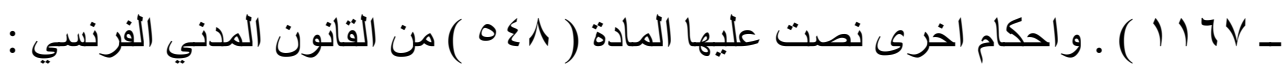

الفرع الاول : وقت بدء حسن النية : يقصد به الوقت الذي يفترض فيه نوافر حسن النية للحائزحتى يتملك الثمار وفقا لقاعدة تملك الثمار بالحيازة ـ ـ ولا يوجد نص في القانون المدني العر اقي او المدني الفرنسي ، يحدد الوقت الذي يبدأ فيه حسن النية ـولكن اغلب الفقهاء يذهبون الى ضرورة توافر حسن النية في كل مرة تقع فيها الحيازة، فهي تتجدد عند كل

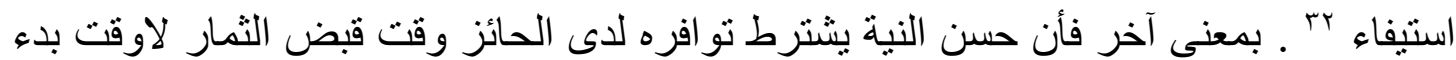

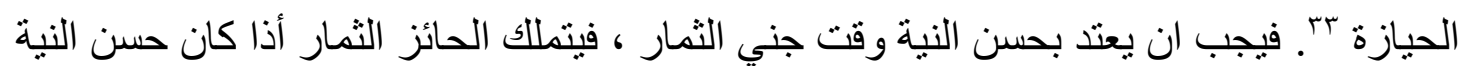
وقتتئذ ، فسوء النية الطاريء يحرم الحائز من تلك الثمار التي يجنيها بعد ذلك ، لأن السبب الذي لني ادى الى كسبه الثمار قد زال \& ـ هذا مع العلم ان تقدير حسن النية يكون بالنسبة الى شخص

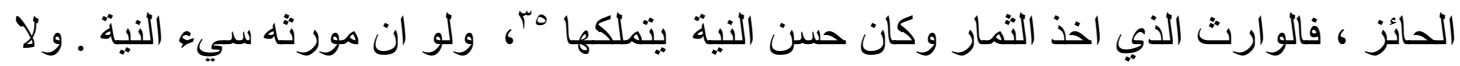
يتملكها اذا كان سيء النية ، ولو ان مورثه حسن النية بّا. وهو ما اتفق عليه الفقهاء ونص عليه القانون المدني العر اقي ، فقد نصت المادة (110 (1) ) ( يملك الحائز حسن النية ما قبضه من زو ائد وما استوفاه من المنافع مدة حيازته ) ـ ونصت عليه المادة ( IVA ) من القانون المدني المصري ( يكسب الحائز ما يقبضه من ثمار مادام حسن النية ) ـ ويكون للحائز الثمار ، اذا كان حسن النية ، سو اء أحصل وضع اليد على عقار ام منقولجّل. 
الفرع الثاني : تحول الحائز الى سيء النية : لايكفي ان يكون حسن النية وقت بدء الحيازة كما

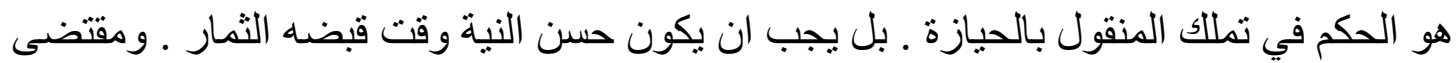

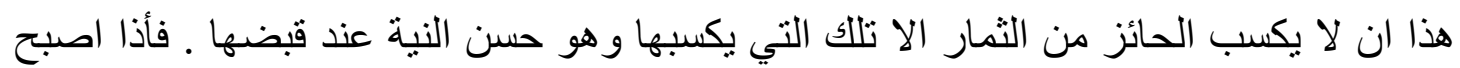

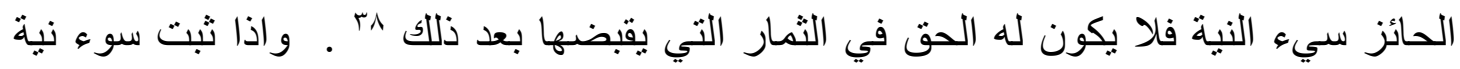
الحائز فأنه لايلتزم فقط بأن برد للمالك الحقيقي الثمار التي قبضها ، بل يلتزم كذلك بقيمة الثمار

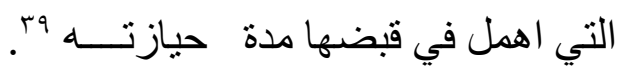

وبموجب الثطر الاخيرمن نص المادة ( .00 ) من القانون الفرنسي ( .. يكف عن كونه حسن

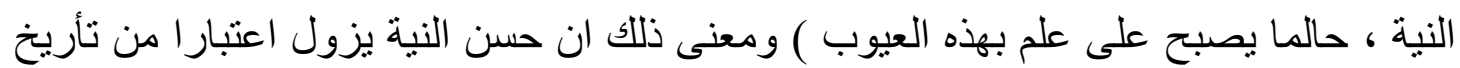

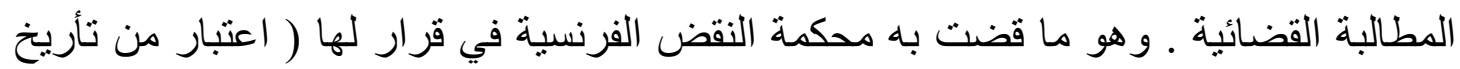

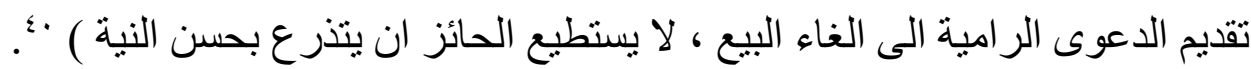

هذا وان اثبات الوقت الذي ينقطع فيه حسن النية عند حائز الثمار ، من الوقائع التي تتثبت منها

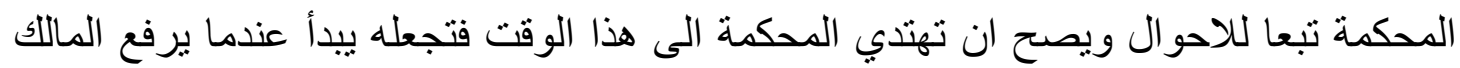

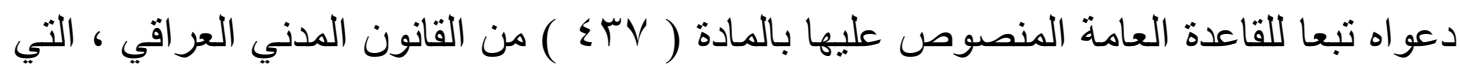

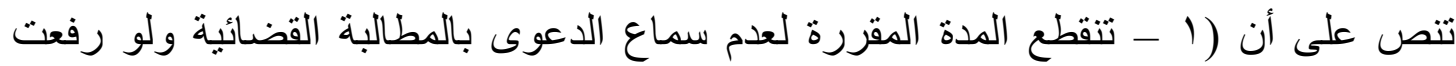
الدعوى الى محكمة غير مختصة عن غلط مغتفر فان طالب الدائن غريمه في الدحكمة ولم تفصل الدعوى حتى مضت الددة فانها تسمع بعدها. r - و وكالمطالبة القضائية الطلب الذي يتقدم به الدائن لقبول حقه في تفليس او توزيع وبوجه عام أي عمل يقوم به الدائن للتمسك بحقه اثناء

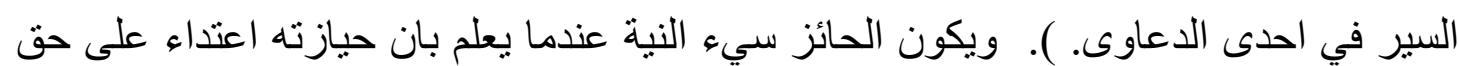

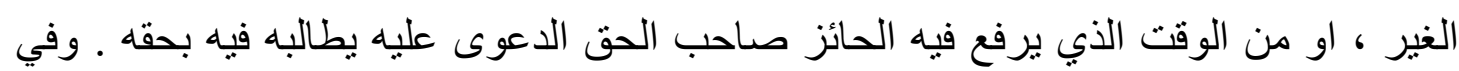
هذه الحالة لايجوز للحائز ان يثبت حسن نيته من يوم رفع الدعوى حتى لو كان في الواقع حسن

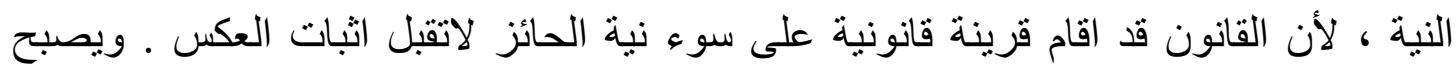

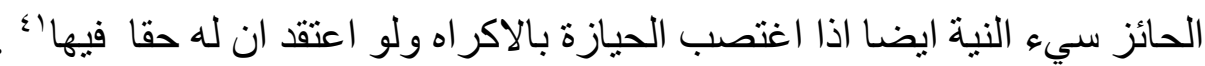




\section{المبحث الثاني}

\section{الاساس القانوني لتملك الثمار بالحيازة واثاره وانتهائه قانونا}

\section{The legal bases of acquisition the fruits by possession}

يترتب على تحديد الاساس القانوني لتملك الثمار، اثارا معينة ـ تختلف بحسب ما اذا كان

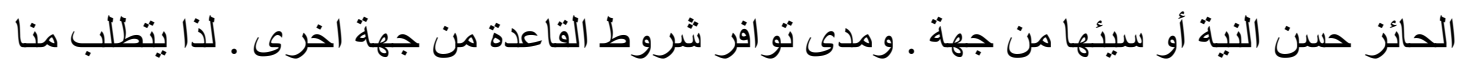

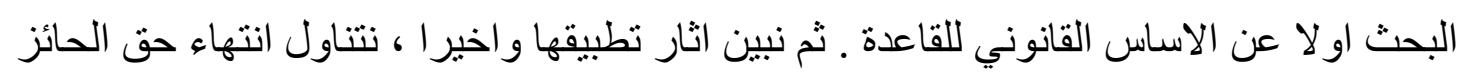

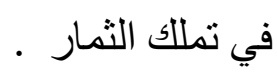

$$
\text { المطلب الاول }
$$

\section{الاتجاهات الققهية}

\section{Trends of jurisprudence}

انقسم الفقه في تحديد الاساس القانوني لتملك الثمار بالحيازة على الاتجاهات التالية :

الاتجاه الاول : يذهب انصار هذا الاتجاه الى ان الاساس القانوني لتملك الحائز للثمار هي قاعدة (

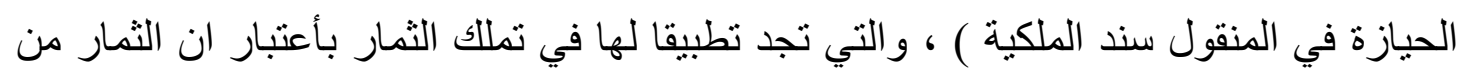

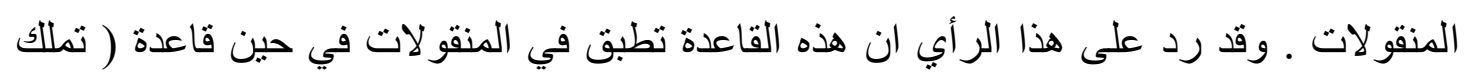

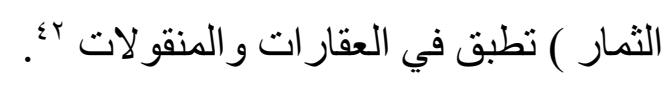

الاتجاه الثاني : يذهب انصار هذا الاتجاه الى ان تملك الثمار بالحيازة تجد اساسا لها في قو اعد

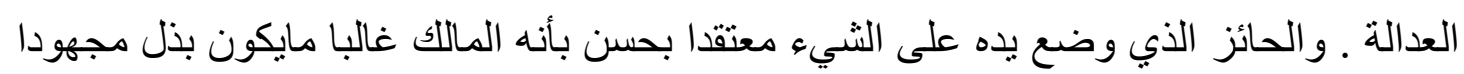

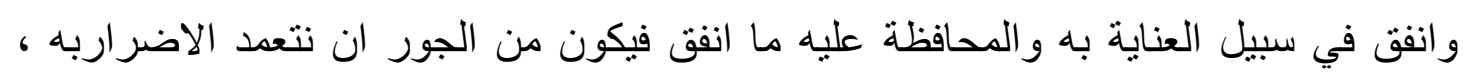

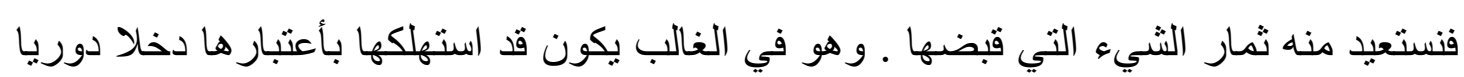

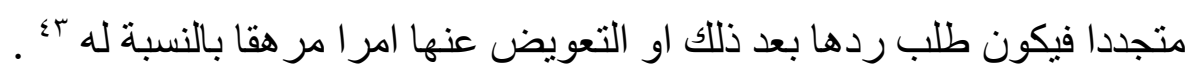

الاتجاه الثالث : يذهب انصار هذا الاتجاه الى اسناد كسب الحائز حسن النية لثمار الثيء، الى

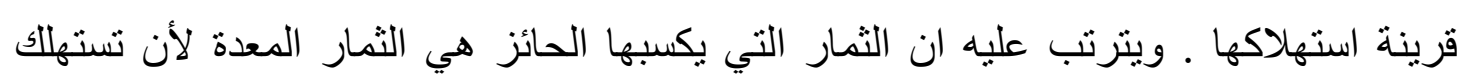

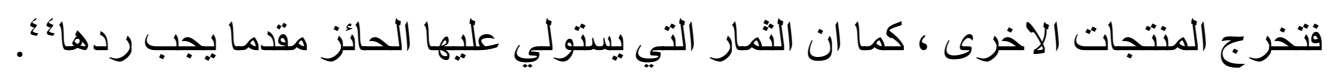


الاتجاه الرابع : انصار هذا الاتجاه برون ان سبب تملك الثمار هنا هي الحيازة المقترنة بحسن النية ـ وهي حيازة تقع على الثيء الاصلي الذي انتج الثمار ، ثم على الثمار نفسها يقبضها ـ فالحيازة هنا ، كما في تملك المنقول بالحيازة وهي سبب الملكية ـ ولكن لايمكن اعتبار قاعدة تملك الحائز للثمار تطبيقا لقاعدة تملك المنقول بالحيازة ، فالحائز يمتلك الثمار لاعتبارات تختلف عن الاعتبار ات التي يمتلك الحائز من اجلها المنقوله؛ .

ونحن نذهب الى الراي الاخير الذي برى ان تملك الثمار يجد اساسه استنادا الى مبدأ الحيازة ،

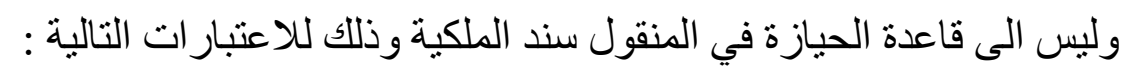

ان قاعدة تملك المنقول بالحيازة تؤسس على مبدأ استقرار التعامل في المنقول ، اما قاعدة تملك الحائز للثمار فتقوم على اعتبار ات تتعلق بحسن نية الحائز وجهله .

ان نطاق تطبيق قاعدة الحيازة بالمنقول يتناول المنقول كثيء اصلي يتملكه الحائز ،

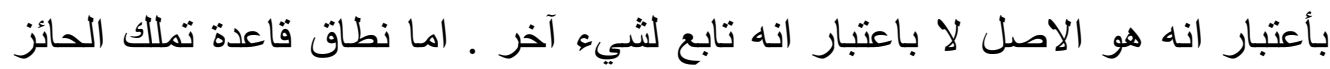

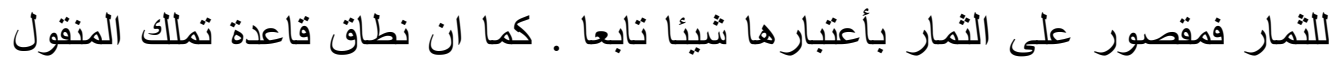
بالحيازة ينحصر في منقول مادي معين بالذات او حق عيني في هذا المنقول ، و لايتناول جميع المال ج؛؛ اما نطاق قاعدة تملك الحائز للثمار ، فيستوي فيها ان يكون الثيء الذي

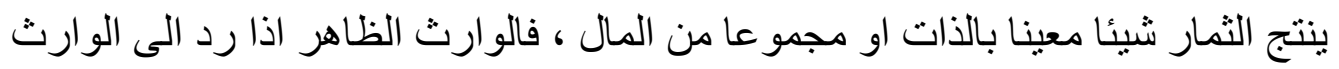
الحقيقي نصييه في التركة يمتلك الثمار التي جناها من هذا النصيب اذا كان النيان الحائز سيء النيةزع .

$$
\text { المطلب الثاني }
$$

\section{الاثر المترتب على تطبيق القاعدة وانتهائها}

\section{The effect of application and termination the rule}

نعني بالاثار ، ايلولة الثمار الى شخص محدد ، و هذه الاثار نص القانون المدني العراقي على

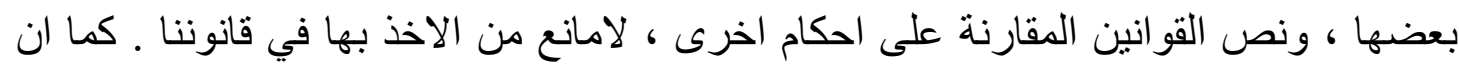

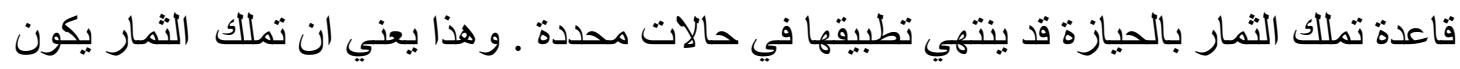


مقيدا بحدود معينة ـ وبناءا على ذلك نبحث اولا الاساس القانوني للقاعدة ـ ثم نبين حالات انتهائها.

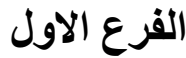

أثار تملك الثمار بالحيازة

\section{The effects of acquisition the fruits by possession}

يترتب على تملك الثمار بالحيازة العديد من الاثار التي تختلف بحسب ما اذا كان الحائز حسن النية او سيئها .

اولا : تملك الثمار بالنسبة لحسن النية : بالرجوع الى نص المادة ( 110 ( ) ( الحائز حسن النية يمتلك ما قبضه من الزو ائد وما استوفاه من المنافع مدة حيازته ) ومصدر النص العر اقي هو نص المادة ( 9§ه ) من القانون المدني الفرنسي ونصها ( لايملك حائز الثيء ثماره الا اذا كان حسن النية في حيازته ، وبخلاف ذلك يلزم بردها مع الاصل الى المالك ...)^ء . وخلاصة ما تقدم ان حسن النية يملك طبقا للنصوص السابقة ثمار الثيء وزوائده استنادا الى حسن النية ، ولكن هذا الامتياز يقف حال علمه بخطأ حيازته ـ و عند ذلك يكون مسؤو لا مسؤولية الثخص المعتاد عن الثمار الحاصلة بعد رفع الدعوى ـ هذا ولايلزم الحائز برد الزوائد التي استولى عليها فاستهلكها ، و لا المنافع التي استوفاها ـ اما مالم بيتولي عليها ولم يستوفها فأنه لاسلطان لله عليها ـ وينطبق على هذا القول القاعدة الثرعية المشهورة ( الاجر و الضمان لا يجتمعان ) ـ و السبب في ذلك ان الز ام الحائز برد ما انتفع به افقارله بانتزاع ما كان قد ملكه ملكا صحيحا باعتقاده لايلام عليه .

ويذهب بعض الفقهاء 9؛ الى ان هذا الحكم هو قريب من قاعدة الكسب دون سبب ، وحكم المادة ( 11 (1) هو ان الحائز يملك ما قبضه من الزوائد وما استوفاه من المنافع مدة حيازته اذا كان حسن النية فقط ـ اما اذا تجاوز الحائز في استعمال مال الغير بحيث اضاف اليه شيئا من

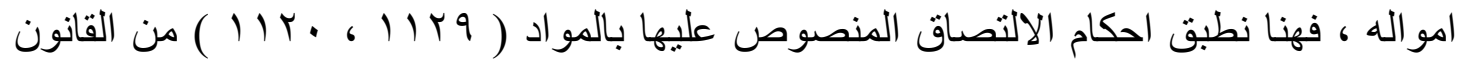

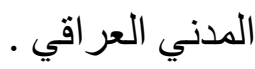


ثانيا : اثار قبض الثمار للحائز سيء النية : يلتزم الحائز سيء النية برد الثمار او التعويض الثي الثيا عنها وفي هذه الحالة يكون للمالك ان يسترد الثيء الذي انتج الثمار ـ وهو ما نصت عليه المادة (1174 ) من القانون الدني العر اقي ( يكون الحائز سيء النية من وقت ان يصبح سيء النية عن جميع الثمار التي يقبضها و التي قصر في قبضها ) ـ وقد يكون سيء النية منذ بدء حيازته ، كما لو كان قد تلقى الثيء الذي انتج الثمار من تركة مورثه وهو يعلم ان المورث لم يكن مالكا

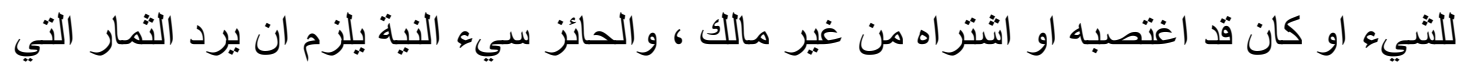
قبضها ـ وهو يلتزم بردها عينا ان كانت ما تز ال موجودة . فأن كان الحائز قد استهلكها فعليه ان يرد قيمتها وقت قبضها ـ وهي الثمار التي كان المالك يجنيها لو ان الثنيء كان في حيازته ، و هويلتزم ثالثا بدفع الفو ائد عن الثمار التي يلتزم بردها بالسعر القانوني من وقت قبضها او من لن

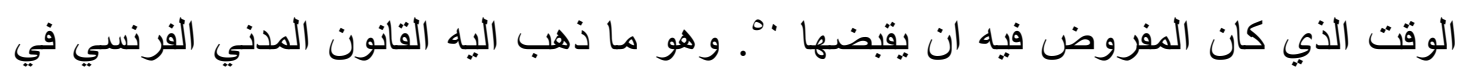

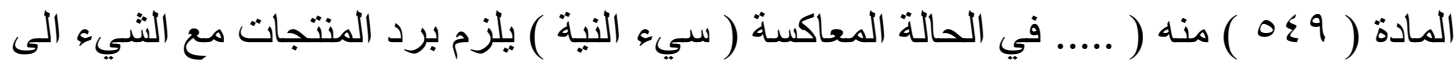
المالك الذي يطالب بها اذا لم تعد المنتجات المذكورة موجودة عينا ، تقدر قيمتها بتأريخ التسديد ). ويكون رد الثمار في القضاء الفرنسي اعتبار من تاريخ المطالبة بملكيتها ـ وهو ما لها لها

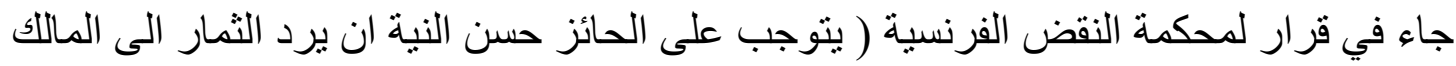

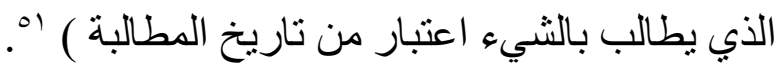

وطبقا لنص المادة ( 1171 ) من القانون المدني العر اقي فأن الحائز سيء النية يكون مسؤو لا

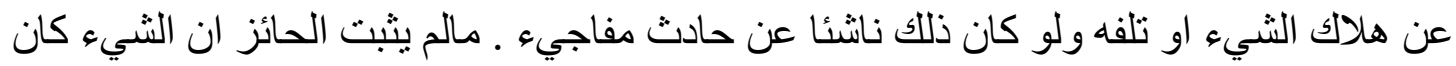
يهلك او يتلف ولو كان باقيا في يد من يستحقه . 


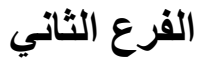 \\ انتهاء حق الحائز في كسب الثمار}

The finish of possessor right to acquisition the fruits

$$
\text { ينتهي حق الحائز في كسب الثمار في حالتين : }
$$

الاولى : حين يزول حسن النية لديه ، وذلك في الوقت الذي يصبح فيه الحائز سيء النية ، اي من

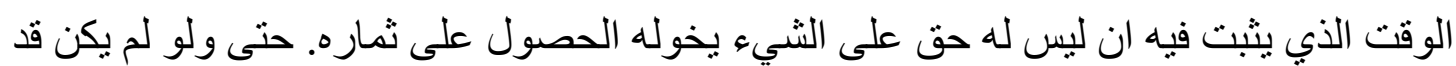

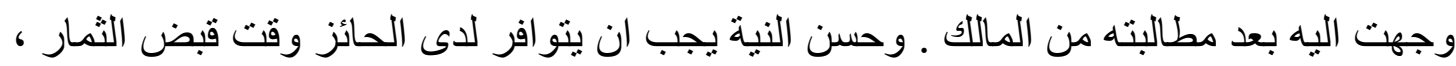

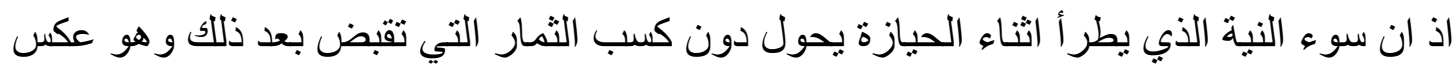

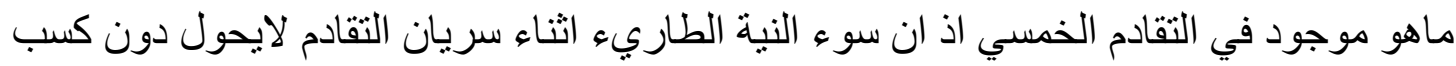

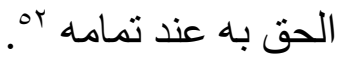

وفي القضاء الفرنسي فأن حسن النية يزول اعتبار امن تاريخ تقديم الدعوى الرامية الى الغاء

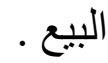

الثانية : حين بعلم الحائز عيوب حيازته من خلال صحيفة الدعوى الموجهه له من قبل المالك .

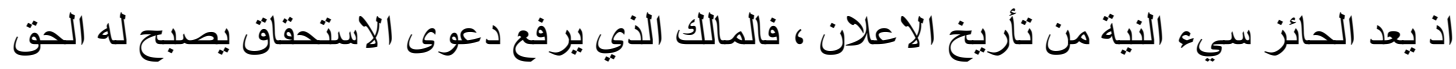

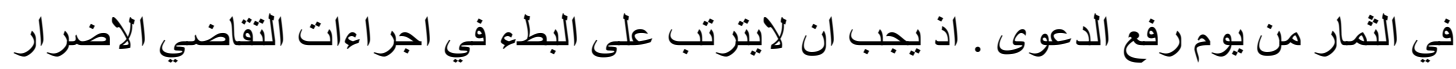
به ، فهو يجب ان يحصل على ما كان يسنطيع الحصول عليه اذا كانت الدعوى قد فصلت فيها

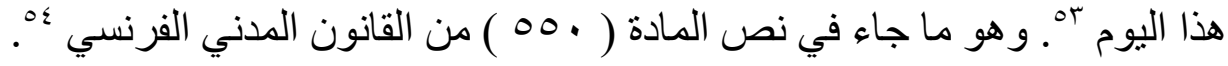




\section{الخاتمة}

\section{Conclusion}

مما تقدم بحثه ، يمكن وضع نقاط اساسية تمثل النتيجة التي توصلنا لها ، ونضع اخيرا

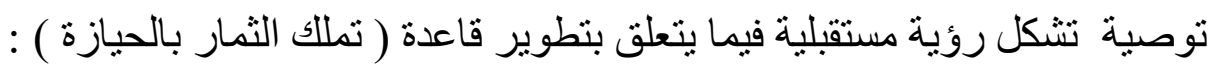
اولا : الاستتتاجات : نستنتج مما سبق بحثه :

I. . ان ركن السبب الصحيح يندمج بركن حسن النية ، ولذا لم تثترط القو انين في قاعدة تملك الثمار بالحيازة ان يكون هناك سبب صحيح مستقل عن حسن النية ـ خلاف قاعدة الحيازة بالمنقول التي يكون ركن السبب الصحيح مستقل عن ركن حسن النية. r ب. يشترط تو افر حسن النية في قاعدة تملك الثمار بالحيازة ، في كل مرة يضع الحائز يده على الثمار ، بخلاف حسن النية في قاعدة تملك المنقول بالحيازة التي يكفي فيها تو افر

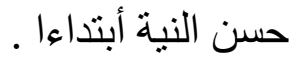

r. ان الحائز حسن النية لا يتحمل ما أصاب المالك من ضرر ، أذا هلكت الثمار وهي في

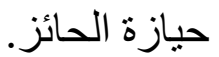
ع. تؤسس قاعدة تملك الثمار بالحيازة على الرأي الاصح على قرينة الحيازة ، ولكنها حيازة من نوع خاص ـ تسري على العقار و المنقول . يلتزم الحائز بأن يرد الى المالك المال الاصلي ، اذا أثبت المالك حق ملكيته على الثيء . تانيا : التوصيات : بناءا على ما تقدم ، نوصي بالاتي :

الرؤية المستقلية هي ضرورة تاصيل قاعدة تملك الثمار بالحيازة على اساس الحيازة ، بحيث تكون مستقلة في قو اعدها ونصوصها القانونية عن قاعدة ( حبازة المنقول سند للملكية ) ، فنشمل

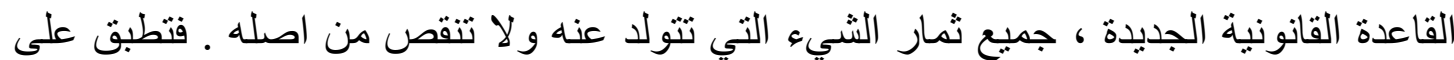
العقار و المنقول على حدا سو اء. 


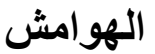

\section{Endnotes}

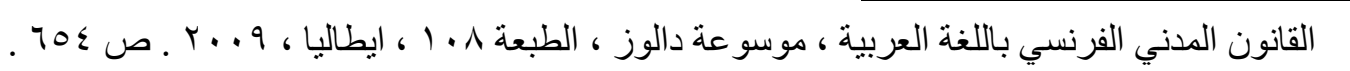

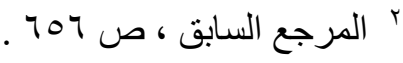

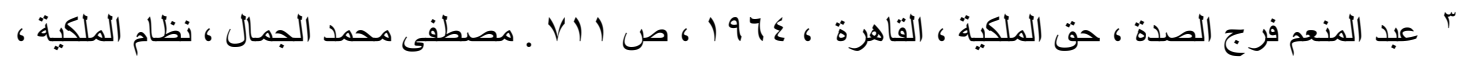

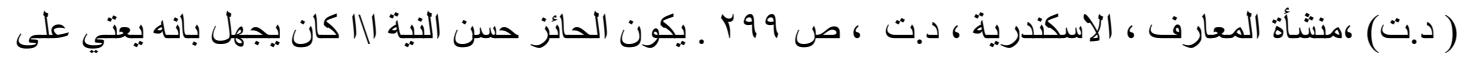
حق الغير ، بمعنى انه يكون حسن النية اذا اعتقد بان الثمار ملك لله ؛ حامد مصطفى ، شرح القانون المدني العر اقي ، الجزء الاول ـ الملكية واسبابها ، شركة التجارة والطباعة

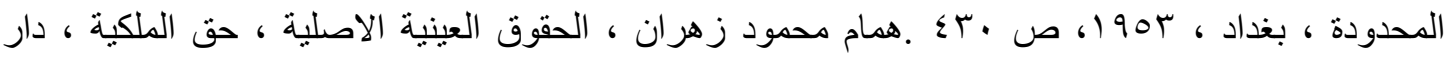

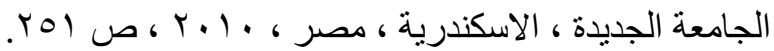
• موسو عة دالوز ، المرجع السابق ، ص 700 .

' اسماعيل غانم ، الحقوق العينية الاصلية ، الجزء الاول ، حق الملكية ، مكتبة عبدالله وهبة ، 1909 1، ص .$\leqslant \leqslant V$

$$
\text { " حامد مصطفى ، المرجع السابق، ص ابrع. }
$$

^ (الفرق بين الاستيفاء والقبض ، هو أن استيفاء الثمار يكون من خلال تعيينها بالوزن ، او العد ، او الكيل ـ أما قبض الثمار فيقصد به جنيها وقطفها بصورة فعلية ).

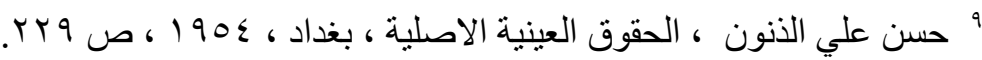

$$
\begin{aligned}
& \text { · عبد المنعم فرج الصدة ، حق الملكية ، ص Y VI. }
\end{aligned}
$$

"' عبد الرزاق السنهوري ، الوسيط في شرح القانون المدني الجديد ، الجزء التاسع ، المجلد الثناني ، أسباب

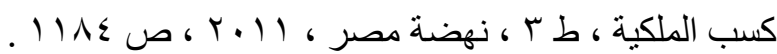

${ }^{12}$ COLIN ET CAPITANT ET JULIOT DE LA MORANDIER; Traite pratique de droit civil , T. II, paris, 1959,P43. 
ء' تتص المادة ( ^ـه ) من القانون المدني الفرنسي على ( الثمار التي ينتجها الثيء لا تخص الملك ، الا بشرط تسديد نفقات الحر اثتة و الاعمال و البذار التي يقوم بها الغير و التي تقدر قيمنها بتاريخ التسديد ) .

$$
\text { 10 موسو عة دالوز ، المرجع السابق ، ص } 700 \text {. }
$$

17 حسن كيره ، الموجز في احكام القانون المدني ، الحقوق العينية الاصلية احكامها ومصادر ها ، منشأة المعارف

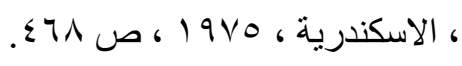

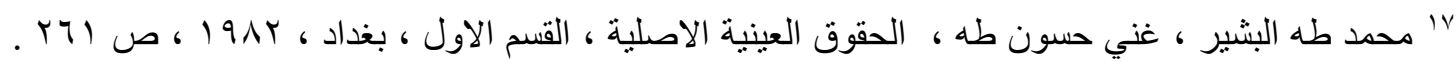

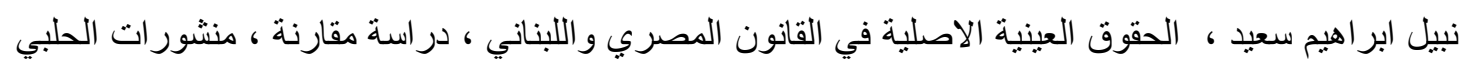

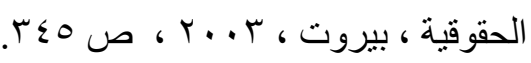

^1 محمد طه البشير ، غني حسون طه ، المرجع السابق ، ص لآب. 19 19 موسو عة دالوز ، المرجع السابق ، ص 707.

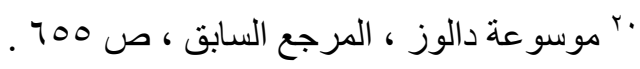

${ }^{21}$ AUBRY ET RAU ; Traite de droit civil francais, T.I. et T.X,6e ,ed, Parir,1951.p 312. RIPERT ET BOULANGER;Traite de droit civil ,T.II,Paris, 1957, P2313.

rr عبد الرزاق السنهوري ، الوسيط في شرح القانون المدني الجديد ، الجزء التاسع اسباب كسب الملكية ،

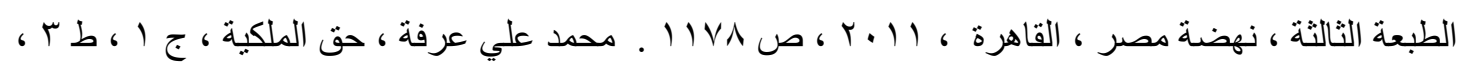

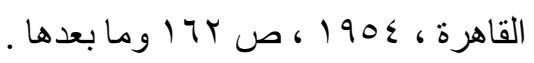

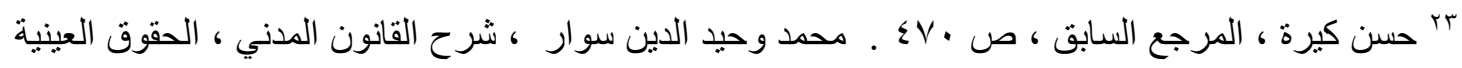

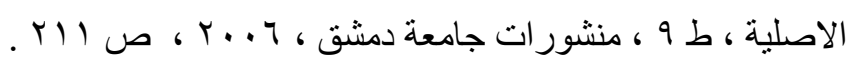

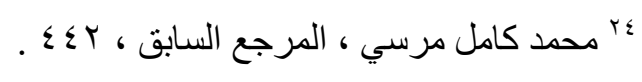

مr توفيق حسن فرج ، الحقوق العينية الاصلية ، مؤسسة الثقافة الجامعية ، الاسكندرية ، ب1911 ، ص ب07 .

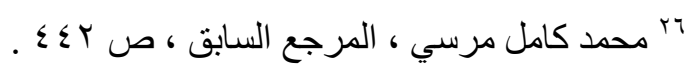

V' منصور مصطفى منصور ، حق الملكية في القانون المدني المصري ، مكتبة عبدالله وهبة ، مصر ، 1970 ، ص 1199. 
${ }^{28}$ PLANIOL, RIPERT ET PICARD; Traite pratique de droit civil francais,T.III, ed, Les biens, Paris, 1952,P174.

$$
\begin{aligned}
& \text { qr محد كامل مرسي ، المرجع السابق ، ص س؟ ؛ . } \\
& \text { • ب دالوز ، المرجع السابق ، ص } 707 .
\end{aligned}
$$

"آ محمد كامل مرسي ، المرجع السابق ، ص 0؟ ؛ـ ـ محمد وحيد الدين سوار ، حق الملكية في ذاته ، الكتاب

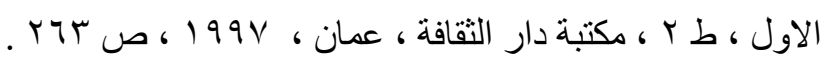

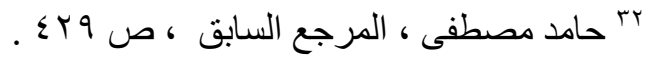

rٓ سعيد عبد الكريم مبارك ، شرح القانون المدني العر اقي ، الحقوق العينية الاصلية ، الطبعة الاولى ، دار

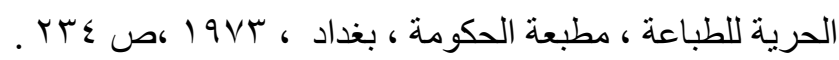

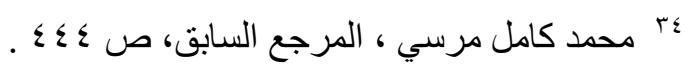

or عبد المنعم فرج الصدة ، محاضرات في القانون المدني ، الملكية في قوانين البلاد العربية، الجزء الثاني ،

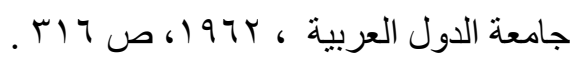
ب"r محمد كامل مرسي ، المرجع السابق ، ص 0؟ ؛ .

${ }^{37}$ COLIN ET CAPITANT, P 904.

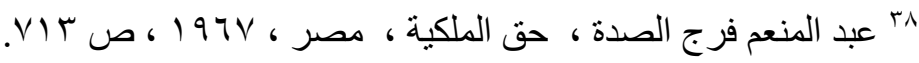

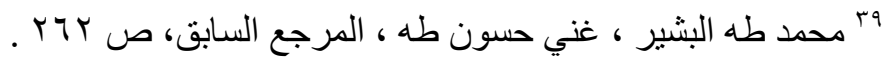

$$
\begin{aligned}
& \text { • بـ دالوز ، المرجع السابق ، ص } 707 .
\end{aligned}
$$

1؛ منصور مصطفى منصور ، حق الملكية ، القاهرة ، 1970 ، ف 111 ـ ـ محد عبد اللطيف ، التقادم المكسب

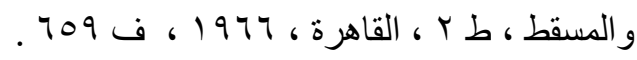

rك عبد المنعم البدراوي ، شرح القانون المدني ، الحقوق العينية الاصلية ، طب ، القاهرة ، 1907 ، ص 101 ـ.

$$
\begin{aligned}
& \text { r؛ محمد طه البشير ، غني حسون طه ، المرجع السابق ، ص . بr. } \\
& \text { ؛ ؛ محمد كامل مرسي ، المرجع السابق ، . ؟ ـ . }
\end{aligned}
$$




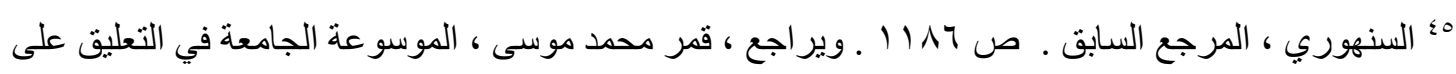

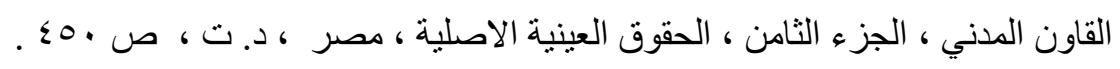
ب؛ صلاح الدين الناهي ، الوجيز في الحقوق العينية الاصلية ، الجزء الاول ، شركة الطبع والنشر الاهلية ،

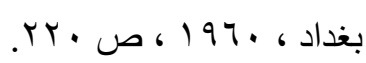

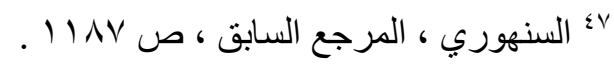
^؛ د دالوز ، المرجع السابق ، ص 700 .

9؛ حامد مصطفى ، المرجع السابق ، ص • • ـ .

• علي هادي العبيدي ، الوجيز في شرح القانون المدني ، الحقوق العينية ، دار الثقافة للنشر و التوزيع ، عمان

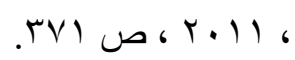

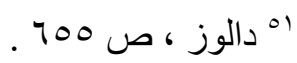

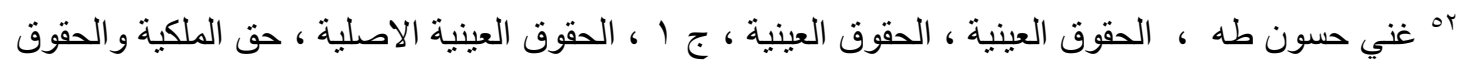

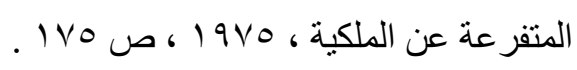

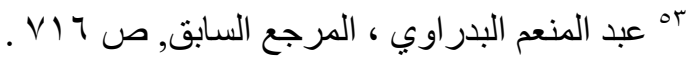
؛ه دالوز ، المرجع السابق ، ص 707. 
المصادر

\section{References}

\section{اولا : المراجع العربية :}

I I اسماعيل غانم ، الحقوق العينية الاصلية ، الجزء الاول ، حق الملكية ، مكتبة عبدالله وهبة ، 1909.

II

حامد مصطفى ، شرح القانون المدني العراقي ، الجزء الاول ـ الملكية واسبابها ، شركة التجارة

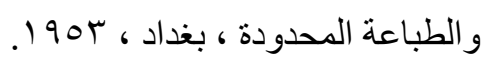

حسن علي الذنون ، الحقوق العينية الاصلية ، بغداد ، 190 ـ .

حسن كيره ، الموجز في احكام القانون المدني ، الحقوق العينية الاصلية احكامها ومصادرها ، منشأة

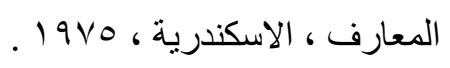

سعيد عبد الكريم مبارك ، شرح القانون المدني العراقي ، الحقوق العينية الاصلية ، الطبعة الاولى ،

صلاح الدين الناهي ، الوجيز في الحقوق العينية الاصلية ، الجزء الاول ، شركة الطبع والنشر ، الندر ، النئ

عبد الرزاق السنهوري ، الوسيط في شرح القانون المدني الجديد ، الجزء التاسع اسباب كسب الملكية

عبد المنعم البدراوي ، شرح القانون المدني ، الحقوق العينية الاصلية ، طץ ، القاهرة ، 907 .

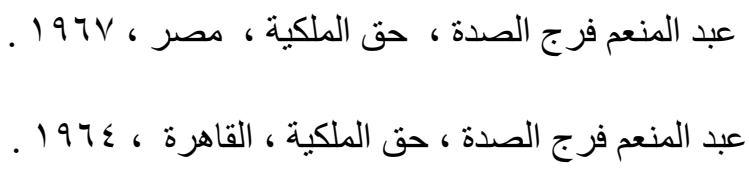

عبد المنعم فرج الصدة ، محاضرات في القانون المدني ، الملكية في قوانين البلاد العربية، الجزء

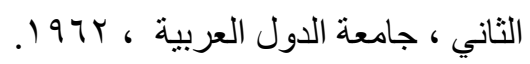


ع علي هادي العبيدي ، الوجيز في شرح القانون المدني ، الحقوق العينية ، دار الثقافة للنشر والتوزيع ،

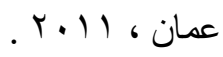

غني حسون طه ، الحقوق العينية ، الحقوق العينية ، ج ا ، الحقوق العينية الاصلية ، حق الملكية

$$
\text { و الحقوق المتفرعة عن الملكية, } 19 \text { ـ ـ }
$$

قمر محمد موسى ، الموسوعة الجامعة في التعليق على القانون المدني ، الجزء الثامن ، الحقوق

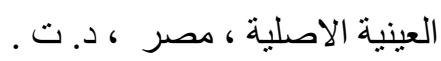

محمد طه البشير ، غني حسون طه ، الحقوق العينية الاصلية ، القسم الاول ، بغداد ، ب19 19 ـ

محمد عبد اللطيف ، التقادم المكسب و المسقط ، ط ب ، القاهرة ، 1977.

محمد وحيد الدين سوار ، شرح القانون المدني ، الحقوق العينية الاصلية ، ط 9 ، منشور ات جامعة

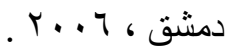

محمد وحيد الدين سوار ، حق الملكية في ذاته ، الكتاب الاول ، ط ب ، مكتبة دار الثقافة ، عمان ،

منصور مصطفى منصور ، حق الملكية في القانون المدني المصري ، مكتبة عبدالله وهبة ، مصر،

، نبيل ابراهيم سعيد ، الحقوق العينية الاصلية في القانون المصري و اللبناني ، دراسة مقارنة .XXIV

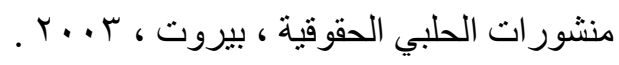

همام محمود زهران ، الحقوق العينية الاصلية ، حق الملكية ، دار الجامعة الجديدة ، الاسكندرية ، 
I. AUBRY ET RAU ; Traite de droit civil francais, T.I. et T.X,6e ,ed, Parir,1951.p 312. RIPERT ET BOULANGER;Traite de droit civil ,T.II,Paris, 1957.

II. COLIN ET CAPITANT ET JULIOT DE LA MORANDIER; Traite pratique de droit civil , T. II, paris, 1959.

III.PLANIOL, RIPERT ET PICARD; Traite pratique de droit civil francais,T.III, ed, Les biens, Paris, 1952.

$$
\begin{aligned}
& \text { I القانون المدني العر اقي رقم •ـ لسنة } 1901 \text { المعدل . } \\
& \text {. القانون المدني المصري رقم اسا لسنة 19 1 المعدل . } \\
& \text {.III }
\end{aligned}
$$

